\title{
The Analysis on Psychology about Employment of Contemporary College Students
}

\author{
Guo-cheng LI \\ Linyi University, Feixian Campus, Feixian, Shandong, China \\ Email:lyulgc@126.com
}

\begin{abstract}
Keywords: College students' employment, Education system, Psychology about the employment.
\end{abstract}

\begin{abstract}
With the gradual advance of reform on socialist market-directed economy system and higher education system, the employment problems of college students will affect the existence of colleges and the development of society directly. The employment of college students are affected by various factors, which are concerned mainly with the government, college, employing unit and the students themselves. Students have encountered much more difficulties in job-hunting, all these setbacks will have direct influence on them mentally and physically. How to recognize vocational choice correctly, to cope with these setbacks, to take part in the social competition in right mindset, to complete challenges, to select a suitable job, are the common concerns of the society, the college schools and the students.
\end{abstract}

\section{Introduction}

With the rapid development of the higher education, the era of mass higher education has come quietly. According to the survey, the total number of college graduates all over the country has reached 6110000 in 2009 , the number reached to 7490000 in 2015 , the employment problems has became the focus of family, college schools and whole society[1]. Facing such employment pressure, the college students recognize the tough job market they are already in, and obviously lack sufficient confidence to confront such situations because the choice they make will be closely related to their future and destiny. Therefore it is imperative to offer college graduates psychological guidance, help them to make good preparations for the job-hunting, to keep up good state of mind, to select a suitable job as soon as possible, and all of above will make great contributions to social stability and the development of national education undertakings. The college students' cognition psychology on employment, which has an important or even decisive influence on students' career choice, consists of students' knowledge about things related to themselves, to career, to the society and employment during the courses of career choice, about the reasoning and decision they have to make on the career choice.

\section{Factors Affecting the Employment of College Students}

\section{Individual Factors}

College Students Tend to Evaluate Themselves Highly and Fail to Judge Themselves Comprehensively and Objectively, Fail to Recognize the Contradiction between Ideal and Reality. Majority of college students lack scientific cognitive style and cognitive means, they don't build up clear and sensible understanding of their vocational interests, personalities, characters and their abilities to obtain employment. They prefer to regard employment more as a process of 
self-development and self-realization than as a way of making a living. Some students prefer to think that the value, the ambition of life will only be realized in the so-called big cities or large enterprises. In blind pursuit of material treatment and regional condition, they lack the painstaking effort and strong sense of responsibility.

College Students Lack Appropriate Channels to Fully Understand Employment Information, Their Employment Value has Sidedness and Limitations. On one hand, college students spend most of their time in campus, they have little access to the real society or vocations; on the other hand, the utility consciousness and values concerning money of college students are rather strong, they prefer the mind to material, prefer the ideal to reality, they put too much expectations on the employment, fail to adapt their employment objectives to social reality, to identify with the self-employment or flexible diverse forms of employment. In a word, college students are unrealistic on employment values[2].

Students' Unsound Personality Leads to a Series of Psychological Problems on Employment. Firstly, anxiety and conflicting emotions. Faced with complicated society, a tough job market and increasingly fierce employment competition, students tend to have such feelings. They would like to select jobs independently while are reluctant to take risks; they are eager for competitions but lack the courage; aimed high but tend to neglect the reality; value the materials and profits as much as the career and intellects; high advocate self-made success while not independent enough, etc.

Secondly, sentiment of inferiority and superiority. Some college students tend to overvalue themselves and aim too high in job-hunting, therefore they will not focus on the job with all their heart. All above will impressed employment units with students' fickleness and lacking of down-to earth manner. On the contrary, some students will lose their nerve, fall into pessimism and form muddle along mentality because of their educational background, capacity, characters and so on, which will cost them the opportunity to show themselves to the employment units.

Thirdly, dependency. Along with the lack of participating awareness and competitive spirit, some college graduates have such strong dependence that they will not take part in the employment competition actively.

\section{Social Factors}

Government. The governmental attention that has been paid on employment of college students is not enough yet, besides, the system for employment is far less mature and perfect than that of European and American countries. Especially that the marketization and legal construction of college students' employment mechanism hasn't been finished yet, therefore, the occupational discrimination existed during students' job-hunting usually will not get corresponding moral or legal restrictions.

College. Firstly, the course set by the college can't keep up with society and fails to meet social demand. The lack of accurate prediction and scientific demonstration on market leads to the problems in students' employment. Secondly, the internal administrative mechanism of colleges still stays in the planned-economy system, and most of teachers are educated under the traditional educational model, as a result, the insufficient quality education on college students won't help to advance students' comprehensive ability to meet the social demand. Thirdly, it's a common phenomenon that colleges overemphasize "input" while neglect "output". The college enrollment is closely related to employment, and because employment usually lags, colleges should adjust the number of enrollment and course design according to the development of economy and social demand for talents, so as to help students to adapt to the 
employment market in four years [3]. However, currently speaking, the enrollment and employment are in the charge of two separate departments, it will easily lead to blind enrollment--- the unwanted majors are jam-packed while the majors in need do not have sufficient enrollment, thus sow the seeds of unemployment after students' graduation.

Employers. firstly, employers have some wrong concepts. Some of them blindly prefer students of higher academic degrees, some enterprises required that the working experiences is a must for students; secondly, the bidirectional choices between employers and student employees titled to the autonomy of employers. During recent years, some employers especially the state-run departments like financial sector, post and telecommunication administration, taxation department, power sector and so on will equip their employees with rather good treatments on salary, benefits, bonuses and houses, all of these are better than the local treatment. Therefore, such employers will attract much more students, it's common to see hundreds of students competing for an opening. What's more, things are getting worse with the increasing big autonomy on talents-selecting of employers, unhealthy tendency like the exchange of privilege for privilege or for money even come into being [4].

\section{Coping Strategies}

According to the above analysis, here I put up my measures of helping college students to adjust their employment psychology.

\section{The Gradual Adjustment and Perfection of College Students Themselves}

Set Up Correct Employment Viewpoint, and Evaluate Themselves Objectively. First of all, it's important for college students to recognize themselves clearly and position themselves appropriately. Second, students should realize that the employment situation is rather grim, also build up their social consciousness and long-term awareness, they can recognize both themselves and the society correctly, only in this way can they find career anchor of them, and also design their professional plan well, and further to combine their ideal with reality so as to form an open employment viewpoint.

Keep a Good State of Mind and Have Objective Understanding of Competence. A good state of mind is necessary in the competitive society. It is common to encounter setbacks in job-hunting, therefore the sense of inferiority is needless. The right thing to do is to accept the failures, and learn from it so as to seek new opportunities.

Foster the Sense Of Starting an Undertaking and Ambitions. Regardless of the hardships and difficulties, start an undertaking, ceaseless self-improvement and be ambitious are not only the requirements of socialist modernization on the young, but also the way for students to realize self-fulfillment, their ambitions and obtain happiness. Only starting from small details and from the base can students make great achievements.

Make Good Preparations for Employment Skills, and Strengthen Employment Competitiveness. College students should combine their majors with the jobs they are going to take in four years, study hard and make their own knowledge structure, master foundational knowledge, foster practical operation ability, scientific thinking ability and organizational coordination ability. Only in this way can students gain their places in fierce competition. 
The Active Assistance and Support of Government to Create Conditions for Employment

The Government Should Strengthen Macro-Regulation and Perfecting Employment Market. The government should formulate regulations conforms to students' employment reality, like household registration management, personnel file administration, the assessment of professional titles, and corresponding policies and compliance measures in social security like the pension insurance and health insurance, thus help students to get rid of their worries behind[5]. Government should establish fair, just and public employment mechanism, build regulated and perfect employment market, provide every talented college student with a stage to show themselves, and help students truly integrate into society and realize life value.

Colleges and Universities Should Deepen the Educational Reform, Strengthen Employment Competences of College Students. Colleges and universities should reform the talent training patterns, deepen the educational reform and push forward quality education reform, cultivate talents that can meet the demand of market, cultivate the professional competence, handling ability, adaptive ability, sustainable competitiveness, innovation ability, ideological quality and psychological quality of college students, to enhance the employment competence of them and provide more employment opportunities for college students[6].

Home-schooling Education Should Be Coordinated with School Education, And the Activity and Initiative of Students Should Be Strengthened. Parents should change their parochialism and traditional employment concepts, lead their sons and daughters to form concepts like " labor equals to employment" " hunting jobs independently", encourage them to take part in the competition, to be independently, to obtain the employment opportunity proactively, thus help them find jobs as soon as possible.

\section{Conclusions}

In conclusion, the employment of college students is a social problem. Students should set up clear aims, enhance their own quality, get rid of the mind of rivalry, anxiety, fear and dependency, advance their psychological and cultural quality. Therefore, college students should try their best to advance their perceived competence, and set up correct employment viewpoint, be realistic, be positive and optimistic, cultivate their own characteristics such as indomitable spirits, bravery, stubbornness and perseverance. Treat the setbacks correctly, keep healthy mindset, build up harmonious interpersonal relationship, select careers suitable to them, apply what they have learned in school into social practices, and serve the society better.

\section{Acknowledgment}

The author wishes to express his sincere thanks to the editor and the anonymous referees for their valuable suggestions and helpful comments which could improve the presentation of the paper.

\section{References}

[1] Sun Xiang, Wang Xiaohu, Changes in the Value Orientation of College Students' Career Choice and Corresponding Measures under Market Economy [J]. Journal of Hefei University of Technology, 2001,15 (2): pp.74-77. 
[2] Xiao Qiang, Research on Guidance of College Students'Employment Viewpoints [J]. Journal of Sichuan University of Science\&Engineering, 2005, 20 (3):pp.118-120.

[3] Chen Qinghua, Employment Viewpoint and Career Guide of Contemporary College Students [J].Journal of Wuhan College of Science \& Technology, 2005, 20 (3):pp.177-179.

[4] Zhang Ling, Who Get Hurt in Employment Market because of the Loss of Credibility [N]. China University Students Career Guide, 2003,04.

[5] Du Desheng, The Problems and Countermeasures Existing in College Students' Employment [J]. Contemporary Culture and Education Research, 2005.02.

[6] Jiang Xuping, Brief Analysis on College Students' Coping with Employment Squeeze [J]. Coastal Enterprises and Science\&Technology, 2008,06. 